J. Lake Sci. (湖泊科学), 2015, 27 (6): 1011-1019

DOI 10. 18307/2015. 0604

(C) 2015 by Journal of Lake Sciences

\title{
土地利用方式影响下的赣江硝态氮浓度和氮稳定同位素分布特征"
}

\author{
王 鹏 $^{1,2,3}$, 齐述华 ${ }^{1,2}$, 陈 波 $^{1,2}$ \\ ( 1 : 江西师范大学鄱阳湖湿地与流域研究教育部重点实验室, 南昌 330022) \\ ( 2 : 江西师范大学地理与环境学院, 南昌 330022 ) \\ (3: 中国科学院陆地水循环及地表过程重点实验室, 北京 100101)
}

摘 要: 赣江硝态氮 $\left(\mathrm{NO}_{3}^{-}-\mathrm{N}\right)$ 是鄱阳湖氮素输人的主要来源, 查明赣江 $\mathrm{NO}_{3}^{-}-\mathrm{N}$ 来源对鄱阳湖的富营养化防治具有重要 意义. 基于 2013 年 1 月和 6 月对赣江干流和主要支流 $\mathrm{NO}_{3}^{-}-\mathrm{N}$ 浓度和 $\delta^{15} \mathrm{~N}_{-} \mathrm{NO}_{3}^{-}$的测定, 通过不同空间尺度和土地类型等 级划分, 分析土地利用方式影响下的竷江 $\mathrm{NO}_{3}^{-}-\mathrm{N}$ 浓度和 $\delta^{15} \mathrm{~N}^{-N_{3}}$ 分布特征. 结果表明, 赣江枯水期和丰水期 $\mathrm{NO}_{3}^{-}-\mathrm{N}$ 浓度 分别为 $0.52 \sim 4.58 \mathrm{mg} / \mathrm{L}$ 和 $0.81 \sim 2.60 \mathrm{mg} / \mathrm{L}$, 均值没有显著性差异; 枯水期和丰水期的 $\delta^{15} \mathrm{~N}^{-\mathrm{NO}_{3}^{-}}$范围分别为 $-1.31 \% 0 \sim$ $8.60 \%$ 和 $2.49 \% 0 \sim 8.51 \%$, 枯水期均值显著小于丰水期. 较大空间尺度的土地利用类型与 $\mathrm{NO}_{3}^{-}-\mathrm{N}$ 浓度和 $\delta^{15} \mathrm{~N}^{-} \mathrm{NO}_{3}^{-}$有更 显著的相关性. 赣江 $\mathrm{NO}_{3}^{-}-\mathrm{N}$ 浓度、 $\delta^{15} \mathrm{~N}^{-\mathrm{NO}_{3}^{-}}$与水田、居民建设用地和水域呈显著正相关, 与林地、草地呈显著负相关, 这 种相关性在丰水期减弱. 与一级土地利用分类相比, 二级土地利用分类能更好地体现土地利用类型与 $\mathrm{NO}_{3}^{-}-\mathrm{N}$ 浓度的相 关性, 但对土地利用类型与 $\delta^{15} \mathrm{~N}^{-\mathrm{NO}_{3}^{-}}$的相关性没有显著提高. 农业用地, 特别是丘陵水田和平原旱地, 是赣江 $\mathrm{NO}_{3}^{-}-\mathrm{N}$ 主 要的污染来源; 与长江流域其它地区相比,赣江流域 $\mathrm{NO}_{3}^{-}-\mathrm{N}$ 的生活污水来源比例较小.

关键词: 竷江; 鄱阳湖; 硝态氮; 氮稳定同位素;土地利用

\section{Characteristics of nitrate and nitrogen stable isotope in Ganjiang River under the influence of land use}

\author{
WANG Peng ${ }^{1,2,3}$, QI Shuhua ${ }^{1,2}$ \& CHEN Bo ${ }^{1,2}$ \\ (1: Key Laboratory of Poyang Lake Wetland and Watershed Research, Ministry of Education, Jiangxi Normal University, Nan- \\ chang 330022, P. R. China) \\ (2: School of Geography and Environment, Jiangxi Normal University, Nanchang 330022, P. R. China) \\ (3: Key Laboratory of Water Cycle and Related Land Surface Processes, Chinese Academy of Sciences, Beijing 100101, P. R. \\ China)
}

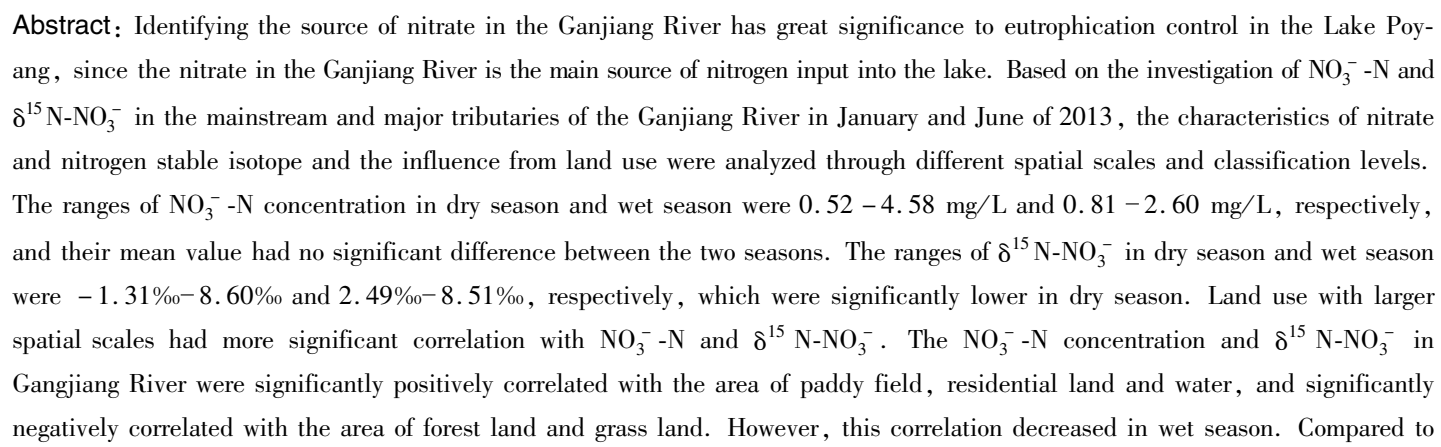

* 国家自然科学基金项目(41201033)、鄱阳湖湿地与流域研究教育部重点实验室主任开放基金项目 (ZK2013009)、 中国科学院陆地水循环及地表过程重点实验室开放基金项目 (WL2013004) 和江西省重大生态安全问题监控协同 创新中心项目 (JXS-EW-00) 联合资助. 2014-12-19 收稿;2015-02-11 收修改稿. 王鹏 (1982 ), 男, 博士, 副教 授;E-mail:wangpengjlu@ gmail.com. 
the first level of land use classification, the second level of land use classification was more helpful to reflect the correlation of land use with $\mathrm{NO}_{3}^{-}-\mathrm{N}$, while little help for $\delta^{15} \mathrm{~N}^{-} \mathrm{NO}_{3}^{-}$. Agricultural land, especially hill paddy field and plain dry land, was the main source of $\mathrm{NO}_{3}^{-}-\mathrm{N}$. Compared with other area in the Yangtze River Basin, there was a smaller proportion of $\mathrm{NO}_{3}^{-}-\mathrm{N}^{-}$coming from domestic sewage in the Ganjiang River Basin.

Keywords: Ganjiang River; Lake Poyang; nitrate; nitrogen stable isotope; land use

河流在陆地表层系统的氮循环中起着重要作用, 随着人为氮素排放的增加, 世界上多数河流的 $\mathrm{NO}_{3}^{-}$浓 度明显增加 ${ }^{[1-2]}$. 大量氮素经由河流汇人水流相对缓慢的湖泊或海湾造成富营养化, 对水环境和饮用水安全 造成严重威胁. 鄱阳湖是我国第一大淡水湖, 也是生态多样性丰富的淡水湿地系统, 近年来随着鄱阳湖流域 的经济发展, 总氮 $(\mathrm{TN})$ 浓度呈逐年上升趋势 ${ }^{[3-4]}$, 面临富营养化的威胁 ${ }^{[5-6]} \cdot \mathrm{NO}_{3}^{-}-\mathrm{N}$ 是鄱阳湖水体中氮素的 主要存在形式, 是引起水体富营养化的重要因子 ${ }^{[7]}$. 赣江是鄱阳湖的第一大支流, 径流量约占鄱阳湖水系总 径流量的 $46.6 \%$. 在鄱阳湖的五大支流中, 赣江 $\mathrm{NO}_{3}^{-}-\mathrm{N}$ 浓度最高, 是鄱阳湖水体无机氮的主要贡献者 ${ }^{[8-9]}$. 查明赣江 $\mathrm{NO}_{3}^{-}-\mathrm{N}$ 的污染来源对赣江流域的水环境保护和鄱阳湖的富营养化防治具有重要意义.

识别 $\mathrm{NO}_{3}^{-}-\mathrm{N}$ 污染源的传统方法是通过调查研究区的土地利用类型并结合水化学特征进行判断 ${ }^{[10-11]}$. 同位素示踪技术的发展为识别河流 $\mathrm{NO}_{3}^{-}$的污染源提供了另外一种有效方法, 不同污染源的 $\delta^{15} \mathrm{~N}^{-\mathrm{NO}_{3}}$ 值具 有不同的变化范围 ${ }^{[12]}$, 通过河水中 $\delta^{15} \mathrm{~N}^{-N_{3}}{ }_{3}^{-}$值可以识别 $\mathrm{NO}_{3}^{-}-\mathrm{N}$ 的污染来源; 但不同污染来源的 $\delta^{15} \mathrm{~N}$ 值存 在范围重叠, 给 $\mathrm{NO}_{3}^{-}-\mathrm{N}$ 来源的判断造成困难 ${ }^{[13]}$. 为提高 $\mathrm{NO}_{3}^{-}-\mathrm{N}$ 污染源识别的准确性, 近年来的研究多将同 位素信息与流域土地利用方式信息结合起来判断氮的污染来源 ${ }^{[14-16]}$. 赣江流域 $\mathrm{NO}_{3}^{-}-\mathrm{N}$ 污染源的研究目前主 要是基于水化学特征分析的方法 ${ }^{[8]}$, 以及不同土地利用方式下的 $\mathrm{NO}_{3}^{-}-\mathrm{N}$ 流失监测 ${ }^{[17]}$, 缺乏结合土地利用方式 和同位素信息的综合分析. 本研究通过赣江流域不同空间尺度和土地类型划分, 分析不同土地利用方式下 $\mathrm{NO}_{3}^{-}-\mathrm{N}$ 浓度和 $\delta^{15} \mathrm{~N}-\mathrm{NO}_{3}^{-}$的分布特征. 研究结果有助于揭示河流 $\mathrm{NO}_{3}^{-}-\mathrm{N}$ 浓度、 $\delta^{15} \mathrm{~N}^{-N_{3}}$ 与流域土地利用的关 系, 为综合利用流域土地利用方式和氮稳定同位素定性及定量识别 $\mathrm{NO}_{3}^{-}-\mathrm{N}$ 的污染来源提供理论依据.

\section{1 材料与方法}

\section{1 样品采集与分析}

于 2013 年 1 月 (枯水期) 和 6 月 (丰水期) 对赣江干流及主要支流河水进行采集, 共设置 20 个采样点 (图 1). 水样在河中心 $50 \mathrm{~cm}$ 深度处提取, 通过 $0.45 \mu \mathrm{m}$ 孔径的醋酸纤维滤膜过滤. $100 \mathrm{ml}$ 水样用于 $\mathrm{NO}_{3}^{-}-\mathrm{N}$ 浓度测定, 装人取样瓶密封; $2 \mathrm{~L}$ 水样用于 $\delta^{15} \mathrm{~N}-\mathrm{NO}_{3}^{-}$测定, 前处理采用 $\mathrm{AgNO}_{3}$ 沉淀法 ${ }^{[18]}$, 操作步骤为: 水样导 人阴离子交换树脂柱进行离子交换, 利用 $3 \mathrm{~mol} / \mathrm{L} \mathrm{HCl}$ 溶液洗脱吸附在树脂柱上的 $\mathrm{NO}_{3}^{-}$; 把盛有洗脱液的离 心瓶放在冷水浴上加人 $\mathrm{Ag}_{2} \mathrm{O}$ 中和, 过滤除去 $\mathrm{AgCl}$ 沉淀, 将滤液冷冻干燥得到固体 $\mathrm{AgNO}_{3}$ 沉淀用于 $\delta^{15} \mathrm{~N}^{-N_{3}}{ }_{3}^{-}$测定. $\mathrm{NO}_{3}^{-}-\mathrm{N}$ 浓度利用戴安 ICS-2100 离子色谱系统测定, $\delta^{15} \mathrm{~N}^{-\mathrm{NO}_{3}^{-}}$利用 Finngan Mat 253 同位素质 谱仪测定.

\section{2 子流域与土地利用类型}

对 S1 S20 采样点, 基于 Aster $30 \mathrm{~m}$ 精度的 DEM 数据, 利用 ArcGIS 的 Hydrology 模块划分采样点对应 的子流域, 相应划分为 20 个子流域. 土地利用数据利用 2010 年秋季获取的无云 Landsat 卫星遥感影像, 经过 几何纠正, 参照《环境状况评价技术规范》(HJ/T 192-2006) 中土地利用分类方法, 基于 ArcInfo Workstation, 并结合人工目视解译获得. 该土地利用体系的一级分类划分为林地、草地、居民建设用地、水域、旱地、水田 和未利用地共 7 种类型, 根据地形地貌、林地郁闭度和草地覆盖度等条件建立二级分类体系 (图 2). 该数据 库经过内业校核和外业核查,一级分类的总体精度达到 $90 \%$ 以上,二级分类精度大于 $85 \%$.

\section{3 数据分析}

利用 ArcGIS 10.0 软件统计分析子流域中各土地利用类型面积, 并计算百分比; 利用 SPSS 19.0 软件计 算子流域土地利用类型与 $\mathrm{NO}_{3}^{-}-\mathrm{N}$ 浓度、 $\delta^{15} \mathrm{~N}^{-\mathrm{NO}_{3}}$ 的相关系数.

为研究不同尺度下土地利用方式对 $\mathrm{NO}_{3}^{-}-\mathrm{N}$ 浓度和 $\delta^{15} \mathrm{~N}-\mathrm{NO}_{3}$ 的影响, 对以下 2 种条件的土地利用类型 划分分别进行相关分析计算. 


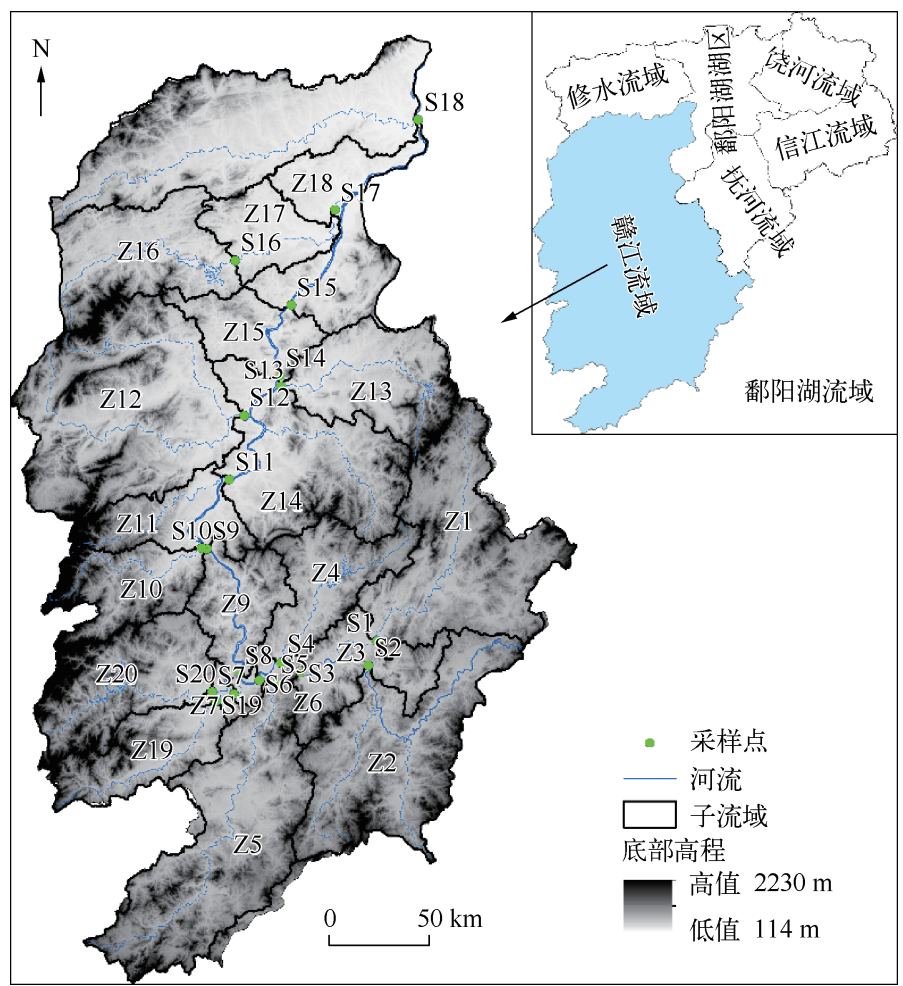

图 1 赣江流域采样点与子流域划分 (S1～S20 表示采样点,Z1 ～Z20 表示相应子流域)

Fig. 1 Sample sites and sub basins in Ganjiang Basin ( $\mathrm{S} 1$ - S20 represent sample sites, and Z1 $-\mathrm{Z} 20$ represent sub basins)

表 1 土地利用分类及代码

Tab. 1 Classifications and codes of Land use

\begin{tabular}{|c|c|}
\hline 一级分类 $($ 代码) & 二级分类 (代码) \\
\hline 水田 & 山区水田 (111); 丘陵水田 (112) ; 平原水田 (113); 大于 $25^{\circ}$ 坡地水田 $(114)$ \\
\hline 旱地 & 山区旱地 (121); 丘陵旱地 (122) ; 平原旱地 (123); 大于 $25^{\circ}$ 坡地旱地 (124) \\
\hline 林地 & $\begin{array}{l}\text { 有林地 }(21) \text { : 郁闭度 }>50 \% \text { 的天然林和人工林; 灌木林 }(22) \text { : 郁闭度 }>40 \% \text { 、高度在 } 2 \mathrm{~m} \text { 以下的矮 } \\
\text { 林地和灌丛林地; 疏林地 }(23) \text { : 郁闭度为 } 10 \% \sim 30 \% \text {; 其它林地 }(24) \text { : 未成林造林地、迹地、苗圈及各 } \\
\text { 类园地 }\end{array}$ \\
\hline 草地 & $\begin{array}{l}\text { 高覆盖度草地 (31) : 覆盖度 > 50\% ; 中覆盖度草地 }(32) \text { : 覆盖度 20\% 50\% ; 低覆盖度草地 (33) : 覆 } \\
\text { 盖度 5\% 20\% }\end{array}$ \\
\hline 水域 & 河渠 (41); 湖泊 (42); 水库坑塘 (43); 滩地 (46) \\
\hline 居民建设用地 & 城镇用地 (51); 农村居民用地 (52); 其它工矿建设用地 (53) \\
\hline 未利用土地 & 沼泽地 (64); 裸土地 (65); 裸岩石砾地 (66) \\
\hline
\end{tabular}

1) 将采样点控制的子流域分为相邻控制流域和总控制流域 2 种空间尺度. 相邻控制流域指从某采样点 至上游相邻采样点间的流域汇水范围, 总控制流域指某采样点在赣江流域内总的流域汇水范围. 如 S3 的相 邻控制流域为 $\mathrm{Z} 3$, 总控制流域为 $\mathrm{Z} 1+\mathrm{Z} 2+\mathrm{Z3}$.

2) 对比分析一级分类和二级分类 2 种方式下, 土地利用类型对 $\mathrm{NO}_{3}^{-}-\mathrm{N}$ 浓度和 $\delta^{15} \mathrm{~N}_{-} \mathrm{NO}_{3}$ 的影响. 


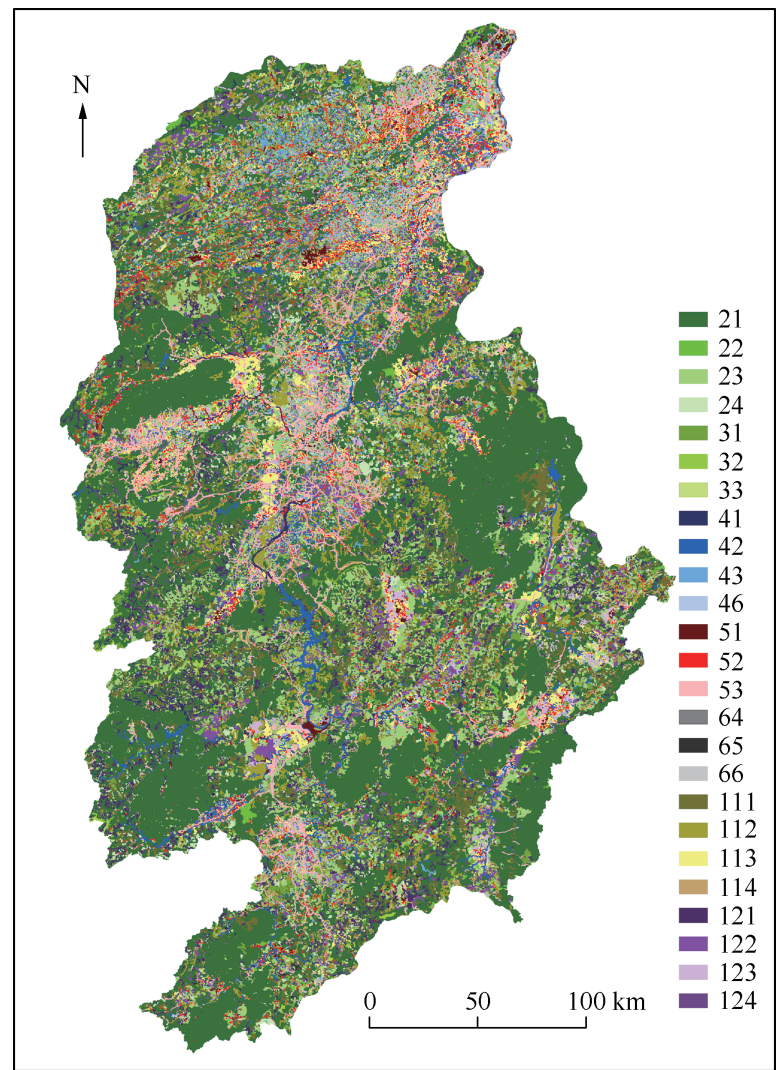

图 2 赣江流域土地利用类型(图例代码见表 1)

Fig. 2 Land use patterns in Ganjiang Basin( Legend code are shown in table 1)

\section{2 结果}

Kolmogorov-Smirnov 正态检验结果表明, 采样点 1 月和 6 月的 $\mathrm{NO}_{3}^{-}-\mathrm{N}$ 浓度以及 6 月的 $\delta^{15} \mathrm{~N}^{-\mathrm{NO}_{3}^{-}}$值都服

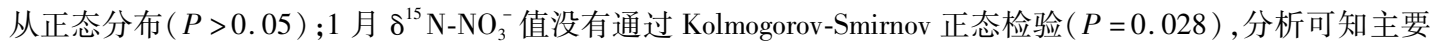
是由于 $S 17$ 点位值异常偏高引起, 忽略 $\mathrm{S} 17$ 点位值影响后数据服从正态分布 $(P>0.05)$. 近似认为各变量接 近正态分布,可用于单变量统计分析和相关性分析.

\section{$2.1 \mathrm{NO}_{3}^{-}-\mathrm{N}$ 浓度和 $\delta^{15} \mathrm{~N}-\mathrm{NO}_{3}^{-}$的分布特征}

$\mathrm{NO}_{3}^{-}-\mathrm{N}$ 浓度从上游到下游没有统一的变化趋势, 枯水期 (1 月) 支流桃江 ( $\mathrm{S} 5$ 点位) $\mathrm{NO}_{3}^{-}-\mathrm{N}$ 浓度最高, 为 $4.58 \mathrm{mg} / \mathrm{L}$, 其次为袁河 ( $\mathrm{S} 17$ 点位, 为 $3.55 \mathrm{mg} / \mathrm{L}$ ) ; 其它干流及支流的 $\mathrm{NO}_{3}^{-}-\mathrm{N}$ 浓度变化范围为 $0.52 \sim$ $2.27 \mathrm{mg} / \mathrm{L}$ (图 3 ). 丰水期 (6 月 ) $\mathrm{NO}_{3}^{-}-\mathrm{N}$ 浓度变化范围小于枯水期, 仍是桃江最高 ( $\mathrm{S} 5$ 点位, 为 $2.60 \mathrm{mg} / \mathrm{L}$ ), 其次为袁河 ( $\mathrm{S} 17$ 点位, 为 $2.36 \mathrm{mg} / \mathrm{L}$ ) ; 其它干流及支流的 $\mathrm{NO}_{3}^{-}-\mathrm{N}$ 浓度变化范围为 $0.81 \sim 1.91 \mathrm{mg} / \mathrm{L}$. 枯水 期 $\mathrm{NO}_{3}^{-}-\mathrm{N}$ 平均浓度为 $1.65 \mathrm{mg} / \mathrm{L}$, 略高于丰水期的 $1.59 \mathrm{mg} / \mathrm{L}$, 但统计学意义上差异不显著 $(P=0.823)$.

枯水期和丰水期的 $\delta^{15} \mathrm{~N}^{-\mathrm{NO}_{3}}$ 范围分别为 - 1.31\% 8.60\%o和 2.49\% 8.51\%o, 枯水期均值为 3.84\%o, 显著小于丰水期均值 $(5.19 \%)(P=0.043) . \mathrm{NO}_{3}^{-}-\mathrm{N}$ 浓度较高的桃江 $\delta^{15} \mathrm{~N}^{-\mathrm{NO}_{3}}$ 较低, 枯水期和丰水期分别为 $-1.31 \%$ 和 $2.49 \%$; $\mathrm{NO}_{3}^{-}-\mathrm{N}$ 浓度较高的袁河 $\delta^{15} \mathrm{~N}^{-\mathrm{NO}_{3}}$ 较高, 枯水期和丰水期分别为 $8.60 \% 0$ 和 $8.36 \%$. 除桃 江与袁河外, 与干流相比, 支流具有较低的 $\mathrm{NO}_{3}^{-}-\mathrm{N}$ 浓度和较高的 $\delta^{15} \mathrm{~N}^{-\mathrm{NO}_{3}}$ 值 (图 4 ). 枯水期支流的 $\mathrm{NO}_{3}^{-}-\mathrm{N}$ 浓度平均为 $1.18 \mathrm{mg} / \mathrm{L}$, 小于干流的均值 $(1.47 \mathrm{mg} / \mathrm{L})$, 但差异不显著 $(P=0.294) ; \delta^{15} \mathrm{~N}^{-\mathrm{NO}_{3}}$ 均值为 $4.62 \%$, 
显著高于干流均值 $\left(3.29 \%\right.$ ) $(P=0.007)$. 丰水期支流的 $\mathrm{NO}_{3}^{-}-\mathrm{N}$ 浓度平均为 $1.15 \mathrm{mg} / \mathrm{L}$, 显著小于干流均值 $(1.76 \mathrm{mg} / \mathrm{L})(P<0.001) ; \delta^{15} \mathrm{~N}-\mathrm{NO}_{3}$ 均值为 $6.28 \%$, 显著高于干流均值 $(4.37 \% 0)(P=0.005)$.
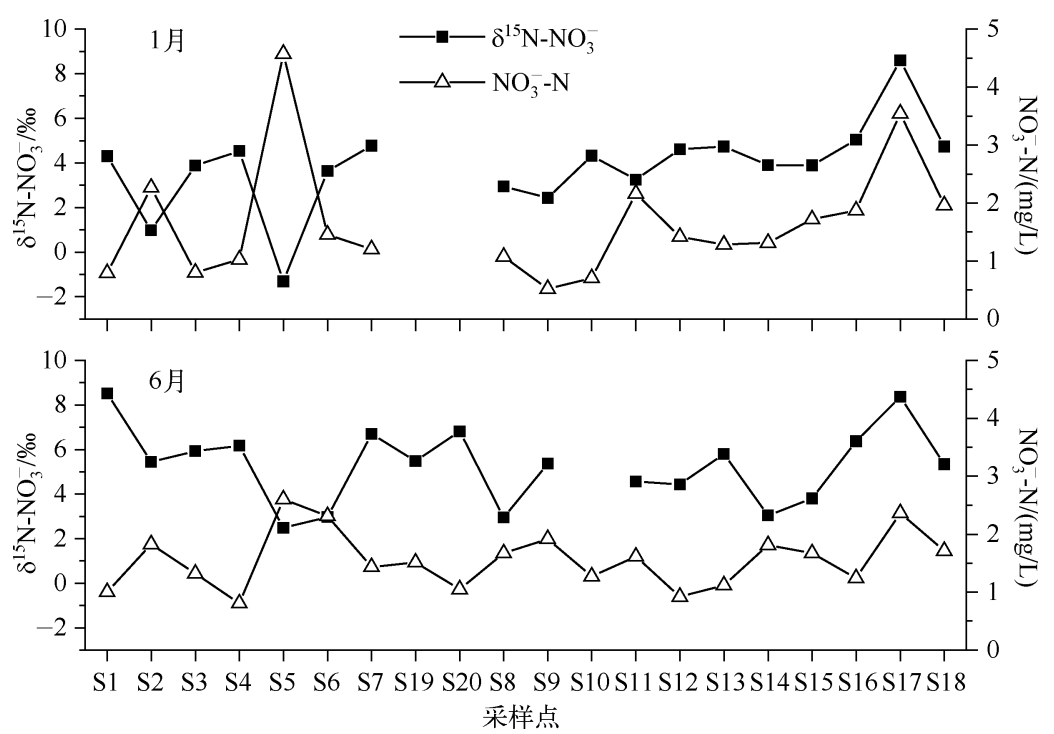

图 3 赣江 $\mathrm{NO}_{3}^{-}-\mathrm{N}$ 浓度和 $\delta^{15} \mathrm{~N}_{-} \mathrm{NO}_{3}^{-}$值的分布

(S19 和 S20 点位只在 6 月采集, $\mathrm{S} 10$ 点位 6 月没有检测出 $\delta^{15} \mathrm{~N}_{-} \mathrm{NO}_{3}^{-}$值)

Fig. 3 Distribution of $\mathrm{NO}_{3}^{-}-\mathrm{N}$ concentration and $\delta^{15} \mathrm{~N}_{-} \mathrm{NO}_{3}^{-}$in the Ganjiang River ( $\mathrm{S} 19$ and S20 sites were only sampled in June, and $\delta^{15} \mathrm{~N}_{-} \mathrm{NO}_{3}^{-}$for S10 site in June was not detected)

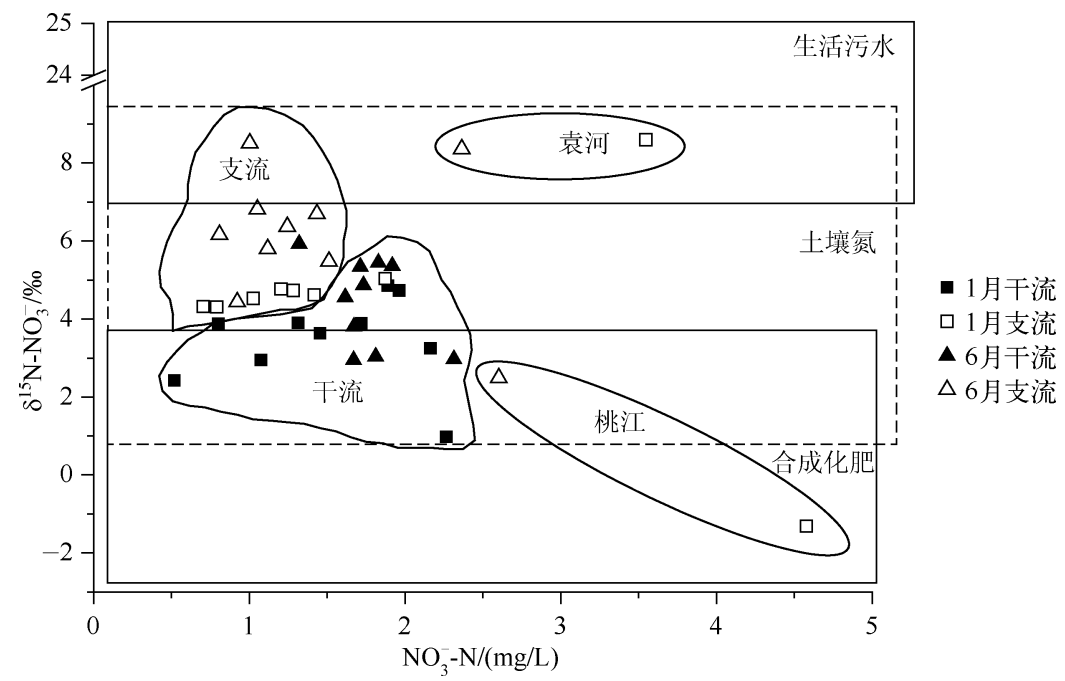

图 4 赣江 $\mathrm{NO}_{3}^{-}-\mathrm{N}$ 浓度和 $\delta^{15} \mathrm{~N}-\mathrm{NO}_{3}^{-}$值的关系

(生活污水、土壤氮和合成化肥的 ${ }^{15} \mathrm{~N}$ 取值范围参考文献 [19-20])

Fig. 4 Relationship of $\mathrm{NO}_{3}^{-}-\mathrm{N}$ concentration and $\delta^{15} \mathrm{~N}^{-} \mathrm{NO}_{3}^{-}$in the Ganjiang River ( Ranges of ${ }^{15} \mathrm{~N}$ for domestic sewage, soil $\mathrm{N}$ and fertilizer are taken from references[19-20]) 


\section{2 土地利用方式与 $\mathrm{NO}_{3}^{-}-\mathrm{N}$ 浓度和 $\delta^{15} \mathrm{~N}-\mathrm{NO}_{3}^{-}$的相关性}

表 2 和表 3 分别为一级分类和二级分类下土地利用方式与 $\mathrm{NO}_{3}^{-}-\mathrm{N}$ 浓度、 $\delta^{15} \mathrm{~N}^{-\mathrm{NO}_{3}^{-}}$的相关性. 一级土地 利用分类下,与相邻控制流域划分方式相比, 1 月总控制流域内的 $\mathrm{NO}_{3}^{-}-\mathrm{N}$ 浓度和 $\delta^{15} \mathrm{~N}^{-} \mathrm{NO}_{3}^{-}$与土地利用类型 呈更显著的相关性，与林地、草地、水田、居民建设用地和水域均有显著相关性. 6 月一级分类和二级分类下 的土地利用方式与 $\mathrm{NO}_{3}^{-}-\mathrm{N}$ 浓度和 $\delta^{15} \mathrm{~N}-\mathrm{NO}_{3}^{-}$的相关性都较差, 仅与草地、水域呈显著相关.

表 2 一级土地利用分类下土地利用类型与 $\mathrm{NO}_{3}^{-}-\mathrm{N}$ 浓度、 $\delta^{15} \mathrm{~N}^{-} \mathrm{NO}_{3}^{-}$的相关性

Tab. 2 Correlation coefficients between land use pattern and $\mathrm{NO}_{3}^{-}-\mathrm{N}$ concentration, $\delta^{15} \mathrm{~N}_{-} \mathrm{NO}_{3}^{-}$ under the first level classification of land use

\begin{tabular}{|c|c|c|c|c|c|c|c|c|}
\hline 流域划分 & 参数 & 月份 & 旱地 & 林地 & 草地 & 水田 & 居民建设用地 & 水域 \\
\hline \multirow[t]{4}{*}{ 相邻控制流域 } & $\mathrm{NO}_{3}^{-}-\mathrm{N}$ & 1 月 & - & - & $-0.67^{* *}$ & $0.49^{*}$ & - & - \\
\hline & & 6 月 & - & - & $-0.57^{*}$ & - & - & $0.58 *$ \\
\hline & $\delta^{15} \mathrm{~N}-\mathrm{NO}_{3}^{-}$ & 1 月 & - & $-0.51^{*}$ & - & $0.59^{\text {*** }}$ & - & - \\
\hline & & 6 月 & - & - & $-0.46^{*}$ & - & - & - \\
\hline \multirow[t]{4}{*}{ 总控制流域 } & $\mathrm{NO}_{3}^{-}-\mathrm{N}$ & 1 月 & - & $-0.55^{*}$ & $-0.63^{* *}$ & $0.54 *$ & $0.62 * *$ & $0.69^{* *}$ \\
\hline & & 6 月 & - & - & - & - & - & - \\
\hline & $\delta^{15} \mathrm{~N}-\mathrm{NO}_{3}^{-}$ & 1 月 & - & $-0.81^{* *}$ & $-0.60^{* *}$ & $0.67^{\text {*** }}$ & $0.55^{*}$ & $0.73^{* *}$ \\
\hline & & 6 月 & - & - & $-0.73^{* *}$ & - & - & - \\
\hline
\end{tabular}

$* *$ 表示在 0.01 水平 $($ 双侧 $)$ 上显著相关, $*$ 表示在 0.05 水平 $($ 双侧 $)$ 上显著相关,下同.

二级土地利用分类下, 1 月 2 种流域划分方式 $\mathrm{NO}_{3}^{-}-\mathrm{N}$ 浓度、 $\delta^{15} \mathrm{~N}^{-\mathrm{NO}_{3}}$ 均与水库坑塘、农村用地呈显著相 关; 与相邻控制流域相比, 总控制流域的划分还体现出 $\mathrm{NO}_{3}^{-}-\mathrm{N}$ 浓度、 $\delta^{15} \mathrm{~N}_{-} \mathrm{NO}_{3}^{-}$与高覆盖度草地、城镇用地的 显著相关, 但水田和旱地的二级分类没有表现出显著相关性. 6 月, 总控制流域内 $\mathrm{NO}_{3}^{-}-\mathrm{N}$ 浓度只与湖泊、城 镇用地显著相关, 相邻控制流域内 $\mathrm{NO}_{3}^{-}-\mathrm{N}$ 浓度与二级土地利用类型呈显著相关, 但没有土地利用类型与 $\delta^{15} \mathrm{~N}^{-\mathrm{NO}_{3}^{-}}$呈显著相关; 总控制流域内 $\delta^{15} \mathrm{~N}-\mathrm{NO}_{3}^{-}$与高覆盖度草地、湖泊显著相关.

表 3 二级土地利用分类下土地利用类型与 $\mathrm{NO}_{3}^{-}-\mathrm{N}$ 浓度、 $\delta^{15} \mathrm{~N}^{-\mathrm{NO}_{3}^{-}}$的相关性

Tab. 3 Correlation coefficients between land use pattern and $\mathrm{NO}_{3}^{-}-\mathrm{N}$ concentration, $\delta^{15} \mathrm{~N}_{-} \mathrm{NO}_{3}^{-}$ under the second level classification of land use

\begin{tabular}{|c|c|c|c|}
\hline 流域划分 & 参数 & 月份 & 相关性结果 \\
\hline \multirow[t]{4}{*}{ 相邻控制流域 } & $\mathrm{NO}_{3}^{-}-\mathrm{N}$ & 1 月 & 水库坑塘 $0.57^{*}$; 农村用地 $0.73^{* *}$; 山区旱地 $-0.63^{* *}$; 平原旱地 $0.64^{* *}$ \\
\hline & & 6 月 & $\begin{array}{l}\text { 湖泊 } 0.50^{*} \text {; 水库坑塘 } 0.53^{*} \text {; 山区水田 }-0.51^{*} \text {; 丘陵水田 } 0.57^{*} \text {; 山区早 } \\
\text { 地 }-0.48^{*}\end{array}$ \\
\hline & $\delta^{15} \mathrm{~N}^{-\mathrm{NO}_{3}^{-}}$ & 1 月 & 水库坑塘 $0.52^{*}$; 农村用地 $0.59^{* *}$; 平原水田 $0.56^{*}$; 平原旱地 $0.54^{*}$ \\
\hline & & 6 月 & - \\
\hline \multirow[t]{4}{*}{ 总控制流域 } & $\mathrm{NO}_{3}^{-}-\mathrm{N}$ & 1 月 & $\begin{array}{l}\text { 高覆盖度草地 }-0.51^{*} \text {; 湖泊 } 0.58^{*} \text {; 水库坑塘 } 0.73^{* *} \text {; 城镇用地 } 0.73^{* * *} \text {; } \\
\text { 农村用地 } 0.65^{* *}\end{array}$ \\
\hline & & 6 月 & 湖泊 $0.52 *$; 城镇用地 $0.55 *$ \\
\hline & $\delta^{15} \mathrm{~N}-\mathrm{NO}_{3}^{-}$ & 1 月 & $\begin{array}{l}\text { 高覆盖度草地 }-0.66^{* *} \text {; 河渠 } 0.64^{* *} \text {; 湖泊 } 0.53^{*} \text {; 水库坑塘 } 0.63^{* *} \text {; 城镇 } \\
\text { 用地 } 0.50^{*} \text {; 农村用地 } 0.56^{*}\end{array}$ \\
\hline & & 6 月 & 高覆盖度草地 $-0.62^{* *}$; 湖泊 $0.46^{*}$ \\
\hline
\end{tabular}

\section{3 讨论}

\section{1 土地利用方式对 $\mathrm{NO}_{3}^{-}-\mathrm{N}$ 浓度的影响}

在一级土地利用分类下, 1 月总控制流域的土地利用类型与 $\mathrm{NO}_{3}^{-}-\mathrm{N}$ 浓度相关性明显高于相邻控制流域 
(表 2). 总控制流域下的相关性表明,农田、居民用地等人类影响强烈的地区对氮素输出起显著“源” 作用, 林地、草地等自然生态景观对氮素输出起 “汇” 作用, 与前人的研究结论 ${ }^{[21-24]}$ 类似. 但在相邻控制流域没有体 现出类似规律. 与 $\mathrm{NH}_{4}^{+}-\mathrm{N}$ 相比, $\mathrm{NO}_{3}^{-}-\mathrm{N}$ 不容易被土壤、植物吸收, 污染源排放的 $\mathrm{NO}_{3}^{-}-\mathrm{N}$ 在流域运移过程中 相对稳定, 较大子流域范围的总控制流域划分方式能更好地体现土地利用类型与 $\mathrm{NO}_{3}^{-}-\mathrm{N}$ 浓度的相关性. Nielsen 等 ${ }^{[25]}$ 认为营养盐在流域内的运移机制决定了输出, 对河流营养盐输人的研究应考虑整个流域. 但在 6 月,2 种空间尺度下的一级土地利用类型与 $\mathrm{NO}_{3}^{-}-\mathrm{N}$ 浓度的相关性都很差, 说明季节因素对子流域的划分 效果也有影响; 与 1 月相比, 6 月气温较高, 植物生长和微生物活动旺盛, $\mathrm{NO}_{3}^{-}-\mathrm{N}$ 更容易被植物吸收或在微 生物作用下发生反硝化等反应, 从而丧失污染源排放的浓度信息, 导致 6 月 2 种空间尺度流域划分方式下土 地利用类型与 $\mathrm{NO}_{3}^{-}-\mathrm{N}$ 浓度无显著相关性.

很多研究表明 ${ }^{[26-28]}$, 农业化肥是河流 $\mathrm{NO}_{3}^{-}-\mathrm{N}$ 的重要来源. 但在一级土地利用分类下, 只在 1 月存在 $\mathrm{NO}_{3}^{-}-\mathrm{N}$ 和水田的显著相关性, 而存在大量化肥施用的 6 月没有显著相关性, 与实际情况不相符. 在二级土地 利用分类下, 按相邻控制流域划分, 山区旱地和山区水田分别在 1 月和 6 月与 $\mathrm{NO}_{3}^{-}-\mathrm{N}$ 浓度呈显著负相关;6 月丘陵水田、平原旱地与 $\mathrm{NO}_{3}^{-}-\mathrm{N}$ 浓度呈显著正相关. 以上表明丘陵水田和平原旱地是赣江 $\mathrm{NO}_{3}^{-}-\mathrm{N}$ 的重要 污染来源, 山区农田的氮素流失较小, 可能是由于山区农田散布于面积广阔的林地间, 流失的氮素经林地吸 收缓冲后, 较少进人河流. 由于不同类型水田、旱地与 $\mathrm{NO}_{3}^{-}-\mathrm{N}$ 浓度相关性的差异性, 一级土地利用分类不能 真实地体现农田对赣江 $\mathrm{NO}_{3}^{-}-\mathrm{N}$ 浓度的影响. 在居民建设用地中, $\mathrm{NO}_{3}^{-}-\mathrm{N}$ 浓度与农村居民用地、城镇用地显 著相关, 体现了生活污水排放的影响; 水域中的湖泊、水库坑塘与 $\mathrm{NO}_{3}^{-}-\mathrm{N}$ 浓度呈显著相关, 体现了氮素的水 生生物来源或渔业养殖的影响. 与一级土地利用分类相似, 在二级土地利用分类下,6 月 $\mathrm{NO}_{3}^{-}-\mathrm{N}$ 浓度与土地 利用类型的相关性比 1 月差.

\section{2 土地利用方式对 $\delta^{15} \mathrm{~N}-\mathrm{NO}_{3}^{-}$的影响}

不同污染源的 $\delta^{15} \mathrm{~N}^{-\mathrm{NO}_{3}^{-}}$具有不同的变化范围 ${ }^{[12,19]}$ ( 图 4), 生活污水 (包括人畜粪汁) 由于氨气的挥发 使剩余 $\delta^{15} \mathrm{~N}^{-\mathrm{NH}_{4}^{+}}$富集, 随后硝化生成的 $\delta^{15} \mathrm{~N}^{-\mathrm{NO}_{3}^{-}}$也相对富集, 约为 7\% $\sim 25 \%$; 其它来源的 $\delta^{15} \mathrm{~N}$ 值相对贫 化, 如各种合成化肥 $(-3 \%$ 3 \% ) 、大气氮沉降 $(-10 \%$ $~ 8 \%$ ) 以及经过矿化作用和硝化作用的土壤氮 $(0 \sim 8 \% 0)$. 本研究中 $\delta^{15} \mathrm{~N}-\mathrm{NO}_{3}$ 范围为 $-1.31 \% 0 \sim 8.60 \%$, 大多位于土壤氮的范围中.

在一级土地利用分类中, 与 $\mathrm{NO}_{3}^{-}-\mathrm{N}$ 浓度类似, 1 月总控制流域的土地利用类型与 $\delta^{15} \mathrm{~N}^{-\mathrm{NO}_{3}^{-}}$相关性明显 好于相邻控制流域, 水田、居民用地、水域与 $\delta^{15} \mathrm{~N}^{-\mathrm{NO}_{3}^{-}}$呈显著正相关, 林地、草地与 $\delta^{15} \mathrm{~N}^{-\mathrm{NO}_{3}^{-}}$呈显著负相关; 6 月土地利用类型与 $\delta^{15} \mathrm{~N}^{-\mathrm{NO}_{3}}$ 相关性较差. Ide 等 ${ }^{[15]}$ 在研究日本 $\mathrm{Hii}$ 河流域时发现, $\delta^{15} \mathrm{~N}-\mathrm{NO}_{3}^{-}$与子流域中农 业用地和居民用地呈正相关, 与森林呈负相关, 并且这种相关性在丰水期减弱. Johannsen 等 ${ }^{[29]}$ 在德国北海 5 条支流的研究中也发现, $\delta^{15} \mathrm{~N}^{-\mathrm{NO}_{3}^{-}}$与流域农业用地和居民用地呈显著正相关. 本研究中 $\delta^{15} \mathrm{~N}^{-\mathrm{NO}_{3}}$ 与林地、 草地呈显著负相关, 与居民建设用地、水域呈显著正相关, 与前者 (土壤氮) 具有较低的 $\delta^{15} \mathrm{~N}^{-\mathrm{NO}_{3}^{-}}$取值范围、 后者 (生活污水) 具有较高的 $\delta^{15} \mathrm{~N}-\mathrm{NO}_{3}^{-}$取值范围相符合. 但水田中的 $\mathrm{NO}_{3}^{-}-\mathrm{N}$ 包含大量农业化肥来源的氮 素, 应具有较低的 $\delta^{15} \mathrm{~N}-\mathrm{NO}_{3}^{-}$值, 即水田面积比例应与 $\delta^{15} \mathrm{~N}^{-\mathrm{NO}_{3}^{-}}$呈负相关. 结果显示 ${ }^{15} \mathrm{~N}-\mathrm{NO}_{3}^{-}$与水田面积比 例呈正相关, 即从水田排水中的 ${ }^{15} \mathrm{~N}^{-\mathrm{NO}_{3}}$ 较高, 表明农业化肥来源的 $\mathrm{NO}_{3}^{-}-\mathrm{N}$ 经历了较强的硝化作用和反硝 化作用, 导致 ${ }^{15} \mathrm{~N}_{-} \mathrm{NO}_{3}^{-}$值升高. 微生物作用下的各种氮反应过程倾向于利用较轻的 ${ }^{15} \mathrm{~N}^{-} \mathrm{NO}_{3}^{-}$, 残留的土壤 $\mathrm{NO}_{3}^{-}-\mathrm{N}$ 库富集了较重的 ${ }^{15} \mathrm{~N}-\mathrm{NO}_{3}^{-}$, 引起 $\delta^{15} \mathrm{~N}^{-} \mathrm{NO}_{3}^{-}$值升高 ${ }^{[29]}$. 在二级土地利用分类中, 平原水田、平原旱地与 $\delta^{15} \mathrm{~N}^{-\mathrm{NO}_{3}^{-}}$呈显著正相关, 可能是由于平原地区径流较弱, 更易于形成还原环境发生反硝化作用, 引起 $\delta^{15} \mathrm{~N}^{-\mathrm{NO}_{3}^{-}}$值升高. 近年来利用同位素混合模型定量计算各污染源对水体 $\mathrm{NO}_{3}^{-}-\mathrm{N}$ 贡献比例的方法得到了广 泛应用, 如 Xue 等 ${ }^{[26]}$ 将同位素混合模型应用于比利时北部地表水 $\mathrm{NO}_{3}^{-}$污染来源的研究, 估算 5 种污染源 (大气沉降 $\mathrm{NO}_{3}^{-}$、合成化肥 $\mathrm{NO}_{3}^{-}$、大气沉降和合成化肥中 $\mathrm{NH}_{4}^{+}$、土壤氮以及生活污水) 的贡献比例. 当污染源 的 ${ }^{15} \mathrm{~N}-\mathrm{NO}_{3}^{-}$信息由于生物化学作用发生显著变化时,该方法的应用会受到限制.

支流桃江和袁河具有较高的 $\mathrm{NO}_{3}^{-}-\mathrm{N}$ 浓度, 但桃江 $\delta^{15} \mathrm{~N}^{-N_{3}}$ 值较小 (枯水期和丰水期分别为 $-1.31 \%$ 、 $2.49 \% 0$ ), 袁河 $\delta^{15} \mathrm{~N}^{-N_{3}} 3$ 值较大 (枯水期和丰水期分别为 $8.80 \%$ 、 $8.36 \%$ ) (图 4). 桃江流域的信丰县, 盛产 脐橙, 是国家商品粮基地县, 赵中华等 ${ }^{[30]}$ 通过氮收支平衡方法在桃江流域建立氮平衡变化模型, 认为农业非 
点源污染是流域氮素输人的主要来源. 桃江流域过高的 $\mathrm{NO}_{3}^{-}-\mathrm{N}$ 浓度可能是由于脐橙种植中大量使用化肥 造成的, 较低的 $\delta^{15} \mathrm{~N}_{-} \mathrm{NO}_{3}^{-}$值也体现出化肥来源的特征. 以上结果表明, 虽然农业来源的 $\mathrm{NO}_{3}^{-}-\mathrm{N}$ 经历了生物 化学反应导致 $\delta^{15} \mathrm{~N}^{-\mathrm{NO}_{3}^{-}}$升高, 但也部分保留了化肥来源的氮同位素信息. $\mathrm{Li}^{\text {等 }}{ }^{[31]}$ 测定长江干流和主要支流 $\delta^{15} \mathrm{~N}^{-N_{3}}{ }_{3}^{-}$值范围为 7.3\% $~ 12.9 \%$, 并认为长江流域 $\mathrm{NO}_{3}^{-}-\mathrm{N}$ 的主要来源为经过硝化作用的土壤氮和城镇污 水; 赣江流域的 $\delta^{15} \mathrm{~N}^{-\mathrm{NO}_{3}^{-}}$值 $(-1.31 \% 0 \sim 8.60 \%$ ) 明显偏低, 表明与长江流域其它地区相比, 赣江流域的 $\mathrm{NO}_{3}^{-}-\mathrm{N}$ 更多来自于农业化肥; 这可能与江西省是农业大省有关. 袁河具有较高的 $\mathrm{NO}_{3}^{-}-\mathrm{N}$ 浓度和 $\delta^{15} \mathrm{~N}^{-} \mathrm{NO}_{3}^{-}$ 值, 应与袁河新余段的城市污水排放有关. $\mathrm{Li}^{\text {等 }}{ }^{[31]}$ 对长江流域 2 个城市污水样品的 $\delta^{15} \mathrm{~N}^{-\mathrm{NO}_{3}}$ 测量值为 $8.9 \% 0$ 和 $9.3 \%$, 与袁河的 $\delta^{15} \mathrm{~N}^{-\mathrm{NO}_{3}^{-}}$值接近; 新余是江西省重要的工业城市, 据 2013 年江西省统计年鉴数据, 新余市工业用水量为 $21.5 \times 10^{8} \mathrm{t}$, 占全省工业用水量的 $33 \%$, 袁河的 $\mathrm{NO}_{3}^{-}-\mathrm{N}$ 可能主要来自工业污水排放.

除污染较重的桃江和袁河外, 与其它支流相比, 赣江干流具有较高的 $\mathrm{NO}_{3}^{-}-\mathrm{N}$ 浓度和较小的 $\delta^{15} \mathrm{~N}^{-\mathrm{NO}_{3}}$ 值 (图 4). 干流流经的土地利用类型受到人类活动的影响更大, 存在更多的城镇和农田灌区, 导致 $\mathrm{NO}_{3}^{-}-\mathrm{N}$ 浓度 较高; 由于干流 $\delta^{15} \mathrm{~N}^{-\mathrm{NO}_{3}^{-}}$值偏小, $\mathrm{NO}_{3}^{-}-\mathrm{N}$ 不会主要来源于生活污水排放或微生物作用下各种氮反应生成的 $\mathrm{NO}_{3}^{-}-\mathrm{N}$, 两者都具有较高的 $\delta^{15} \mathrm{~N}-\mathrm{NO}_{3}^{-}$值; 干流 $\mathrm{NO}_{3}^{-}-\mathrm{N}$ 应主要受 $\delta^{15} \mathrm{~N}-\mathrm{NO}_{3}^{-}$值较低的化肥氮影响. 徐刘凯 等 ${ }^{[32]}$ 利用输出系数法估算了竷江下游流域 $\mathrm{TN}$ 的非点源污染负荷, 认为在 $\mathrm{TN}$ 贡献方面畜禽养殖大于农田, 与本文结论并不相符, 这可能是由于畜禽养殖水中 $\mathrm{TN}$ 以 $\mathrm{NH}_{4}^{+}-\mathrm{N}$ 为主, $\mathrm{NO}_{3}^{-}-\mathrm{N}$ 相对较少, 另外输出系数法 本身也存在很大的不确定性. 王毛兰等 ${ }^{[33]}$ 测定人鄱阳湖口的赣江南支和北支沉积物 $\delta^{15} \mathrm{~N}$ 值分别为 $3.17 \%$ 和 $4.46 \%$, 并认为沉积物氮素的主要来源为土壤氮和人工合成化肥, 与本次赣江干流河水的分析结果相近.

\section{4 结论}

1) 赣江流域枯水期 $\mathrm{NO}_{3}^{-}-\mathrm{N}$ 浓度变化范围大于丰水期, 均值没有显著性差异; 枯水期 $\delta^{15} \mathrm{~N}-\mathrm{NO}_{3}$ 均值显 著小于丰水期. 流域 $\mathrm{NO}_{3}^{-}-\mathrm{N}$ 浓度最高值出现在桃江和袁河下游, $\delta^{15} \mathrm{~N}_{-} \mathrm{NO}_{3}$ 取值表明桃江的 $\mathrm{NO}_{3}^{-}-\mathrm{N}$ 污染主要 来自农业化肥, 袁河主要来自城镇污水. 除污染较重的桃江和袁河外, 与其它支流相比, 赣江干流具有较高 的 $\mathrm{NO}_{3}^{-}-\mathrm{N}$ 浓度和较小的 $\delta^{15} \mathrm{~N}^{-\mathrm{NO}_{3}^{-}}$值.

2) 与相邻控制流域划分方式相比, 总控制流域内的土地利用类型与 $\mathrm{NO}_{3}^{-}-\mathrm{N}$ 浓度和 $\delta^{15} \mathrm{~N}^{-\mathrm{NO}_{3}^{-}}$有更显著 的相关性. 枯水期赣江流域 $\mathrm{NO}_{3}^{-}-\mathrm{N}$ 浓度、 $\delta^{15} \mathrm{~N}^{-\mathrm{NO}_{3}^{-}}$与水田、居民建设用地和水域呈显著正相关, 与林地、草 地呈显著负相关, 相关性在丰水期减弱. 与一级土地利用分类相比, 二级土地利用分类可更好地体现出土地 利用类型与 $\mathrm{NO}_{3}^{-}-\mathrm{N}$ 浓度的相关性,但对土地利用类型与 $\delta^{15} \mathrm{~N}-\mathrm{NO}_{3}^{-}$的相关性没有显著提高.

3 ) 赣江 $\mathrm{NO}_{3}^{-}-\mathrm{N}$ 的主要污染来源是农业用地、居民建设用地和水域. 农业用地, 特别是其中的丘陵水田 和平原旱地, 是赣江 $\mathrm{NO}_{3}^{-}-\mathrm{N}$ 最重要的污染来源; 农田来源的 $\mathrm{NO}_{3}^{-}-\mathrm{N}$ 经历了较强微生物作用下的生物化学 反应, $\delta^{15} \mathrm{~N}^{-\mathrm{NO}_{3}^{-}}$值升高. 与长江流域其它地区相比,赣江 $\mathrm{NO}_{3}^{-}-\mathrm{N}$ 的生活污水来源比例较小.

致谢: 本研究的同位素分析实验得到中国科学院遗传与发育生物学研究所的研究生赵焕、孔晓乐和梁慧雅 的帮助, 在此表示感谢.

\section{5 参考文献}

[ 1 ] Mcisaac GF, David MB, Gertner GZ et al. Eutrophication: Nitrate flux in the Mississippi River. 2001, 414(6860): 166167.

[ 2 ] Townsend-Small A, Mccarthy MJ, Brandes JA et al. Stable isotopic composition of nitrate in Lake Taihu, China, and major inflow rivers. Hydrobiologia, 2007, 194: 135-140.

[3] 余进祥, 刘娅菲, 钟晓兰等. 鄱阳湖水体富营养化评价方法及主导因子研究. 江西农业学报,2009,21(4):125-128.

[4] 陈晓玲, 张 媛, 张 琍等. 丰水期鄱阳湖水体中氮、磷含量分布特征. 湖泊科学, 2013,25 (5):643-648. DOI 10. 18307/2013.0504.

[ 5 ] Wu Z, Cai Y, Liu X et al. Temporal and spatial variability of phytoplankton in Lake Poyang: The largest freshwater lake in China. Journal of Great Lakes Research, 2013, 39(3) : 476-483.

[6] 刘倩纯,余 潮,张 杰等. 鄱阳湖水体水质变化特征分析. 农业环境科学学报,2013,(6):1232-1237. 
[ 7 ] 王毛兰,周文斌. 鄱阳湖水体无机氮时空分布特征研究. 人民长江,2010,41(1):88-91.

[8] 王毛兰, 周文斌, 胡春华. 赣江流域水体无机氮分布特征. 南昌大学学报:理科版,2007,31(3):271-275.

[9] 王毛兰,胡春华,周文斌. 丰水期鄱阳湖氮磷含量变化及来源分析. 长江流域资源与环境,2008,17(1):138-142.

[10] Ohte N, Dahlgren RA, Silva SR et al. Sources and transport of algae and nutrients in a Californian river in a semi-arid climate. Freshwater Biology, 2007, 52 (12) : 2476-2493.

[11] 陈法锦, 李学辉, 贾国东. 氮氧同位素在河流硝酸盐研究中的应用. 地球科学进展, 2007, (12):1251-1257.

[12] Kendall C. Tracing nitrate sources and cycling in catchments. In: Kendall C, McDonnell JJ eds. Isotope tracers in catchment hydrology. Amsterdam: Elsevier, 1998: 519-576.

[13] Bedard-Haughn A, Van Groenigen JW, Van Kessel C. Tracing ${ }^{15} \mathrm{~N}$ through landscapes: potential uses and precautions. Journal of Hydrology, 2003, 272 (1/2/3/4) : 175-190.

[14] Voss M, Deutsch B, Elmgren R et al. Source identification of nitrate by means of isotopic tracers in the Baltic Sea catchments. Biogeosciences, 2006, 3(4) : 663-676.

[15] Ide J, Somura H, Nakamura T et al. Hydrological effects on relationships between $\delta^{15} \mathrm{~N}$ of river nitrate and land use in a rural river basin, western Japan. River Research and Applications, 2014. DOI: 10. 1002/rra. 2756.

[16] 王开然, 郭 芳, 姜光辉等. ${ }^{15} \mathrm{~N}$ 和 ${ }^{18} \mathrm{O}$ 在桂林岩溶水氮污染源示踪中的应用. 中国环境科学, 2014, 34(9): 2223-2230.

[17］向速林. 赣江流域农田地表径流氮磷迁移与流失研究. 生态环境学报,2013,22(7):1204-1207.

[18] Silva S R, Kendall C, Wilkison DH et al. A new method for collection of nitrate from fresh water and the analysis of nitrogen and oxygen isotope ratios. Journal of Hydrology,2000, 228(1/2) : 22-36.

[19] Nestler A, Berglund M, Accoe F et al. Isotopes for improved management of nitrate pollution in aqueous resources: review of surface water field studies. Environmental Science and Pollution Research, 2011, 18(4) : 519-533.

[20] Xue D, Botte J, De Baets B et al. Present limitations and future prospects of stable isotope methods for nitrate source identification in surface-and groundwater. Water Research, 2009, 43(5) : 1159-1170.

[21] 罗 璇,史志华,尹 炜等. 小流域土地利用结构对氮素输出的影响. 环境科学, 2010,31(1):58-62.

[22] Bu H, Meng W, Zhang Y et al. Relationships between land use patterns and water quality in the Taizi River basin, China. Ecological Indicators, 2014, 41 : 187-197.

[23] 孙然好,陈利顶,王 伟等. 基于 “源” “汇” 景观格局指数的海河流域总氮流失评价. 环境科学, 2012,33 (6): 1784-1788.

[24] 李兆富,杨桂山, 李恒鹏. 西苕溪典型小流域土地利用对氮素输出的影响. 中国环境科学,2005,25(6):678-681.

[25] Nielsen A, Trolle D, Søndergaard M et al. Watershed land use effects on lake water quality in Denmark. Ecological Applications, 2012, 22(4) : 1187-1200.

[26] Xue D, De Baets B, Van Cleemput O et al. Use of a Bayesian isotope mixing model to estimate proportional contributions of multiple nitrate sources in surface water. Environmental Pollution, 2012, 161 : 43-49.

[27] Smith EL, Kellman LM. Examination of nitrate concentration, loading and isotope dynamics in subsurface drainage under standard agricultural cropping in Atlantic Canada. Journal of Environmental Management, 2011, 92 (11) : $2892-2899$.

[28] 陈惟财,陈伟琪, 张珞平等. 九龙江流域地表水中硝酸盐来源辨析. 环境科学,2008,29(6):1484-1487.

[29] Johannsen A, Dähnke K, Emeis K. Isotopic composition of nitrate in five German rivers discharging into the North Sea. Organic Geochemistry, 2008, 39(12) : 1678-1689.

[30］赵中华,邱祖民. 桃江流域农业区氮平衡及时空差异性. 水电能源科学,2012,30(5):83-86.

[31] Li S, Liu C, Li J et al. Assessment of the sources of nitrate in the Changjiang River, China using a nitrogen and oxygen isotopic approach. Environmental Science \& Technology, 2010, 44(5) : 1573-1578.

[32] 徐刘凯,王全金,向速林等. 赣江下游地区各类非点源污染源的影响研究. 华东交通大学学报,2012,(1):48-53.

[33] 王毛兰,赖建平, 胡珂图等. 鄱阳湖表层沉积物有机碳、氮同位素特征及其来源分析. 中国环境科学, 2014,34(4): 1019-1025. 